\title{
(息)
}

Citation:

Wood, EH and Yaning Li, N and Thomas, R (2017) Innovation implementation: harmony and conflict in Chinese modern music festivals. Tourism Management, 63. pp. 87-99. ISSN 0261-5177 DOI: https://doi.org/10.1016/j.tourman.2017.06.009

Link to Leeds Beckett Repository record:

https://eprints.leedsbeckett.ac.uk/id/eprint/3794/

Document Version:

Article (Accepted Version)

The aim of the Leeds Beckett Repository is to provide open access to our research, as required by funder policies and permitted by publishers and copyright law.

The Leeds Beckett repository holds a wide range of publications, each of which has been checked for copyright and the relevant embargo period has been applied by the Research Services team.

We operate on a standard take-down policy. If you are the author or publisher of an output and you would like it removed from the repository, please contact us and we will investigate on a case-by-case basis.

Each thesis in the repository has been cleared where necessary by the author for third party copyright. If you would like a thesis to be removed from the repository or believe there is an issue with copyright, please contact us on openaccess@leedsbeckett.ac.uk and we will investigate on a case-by-case basis. 


\section{Innovation implementation: harmony and conflict in Chinese modern music festivals}

\section{Abstract}

There is a degree of consensus in the academic literature that innovation is a vital source of competitive advantage in tourism. Although some processional aspects of innovation have been examined in detail, the process of implementation of innovation at an organisational level has been neglected, especially in the tourism literature. This paper adopts a relational perspective to examine the implementation of innovation within the burgeoning Chinese modern music festivals sector. The findings of six detailed case studies show how identity, equality, guanxi, and a range of specific contextual factors, influence the development of relationships. These, in turn, affect innovation implementation, notably by influencing the acquisition and use of knowledge and other resources essential to the process. A conceptual model is proposed which explains the complexities of these relationships, their roles in innovation implementation, and incorporates mediating factors such as temporality, organisational structure, and the reliance upon volunteers found within events.

Keywords: innovation; events; social exchange; guanxi 


\section{INTRODUCTION}

Innovation in tourism has attracted significant academic interest in recent years (e.g. Brooker \& Joppe, 2014; Carmisón \& Monfort-Mir, 2012; Hall \& Williams, 2008; Hjalager, 2010; Krizaj et al., 2014). This has ranged from research on destination and national tourism innovation systems (e.g. Carlisle et al., 2013; Hall, 2009; Rodriguez et al., 2014; Weidenfeld, 2013) to explanations for differing levels of innovation on various spatial or sub-sectoral scales (e.g. Hjalager, 2015; Sorensen, 2007; Weidenfeld et al., 2010). Though slow to emerge, there has also been a growth in the number of studies reporting research on innovation in commercial tourism organisations (e.g. Nieves \& Segarra-Ciprés, 2015; Thomas \& Wood, 2014, 2015) and on events and festivals (e.g. Carlsen et al., 2010; Paleo \& Wijnberg, 2008; Van Limburg, 2008; Yaghmour \& Scott, 2009). This paper examines an aspect of innovation in an under-research commercial context, namely modern music festivals in China.

Chinese modern music festivals organized by private companies tend to be held in large cities where market opportunities make them financially viable. Smaller cities (or counties) also host this genre of festival but they are usually supported financially by local government as a means of promoting particular economic and cultural visions of places, as happens elsewhere in the world (Getz \& Page, 2016; Schilbach, 2010). Although impossible to quantify precisely, the number of festivals in China which adopt a Western format is growing rapidly and their dynamic nature provides tourism researchers with numerous examples of managerial, organisational, product and process innovations. 
To date, most commentators have focused upon particular aspects of the innovation process, especially those relating to the role of knowledge and knowledge flows (e.g. Czernek, 2017; Shaw, 2015; Shaw \& Williams, 2009; Thomas, 2012; Williams \& Shaw, 2011). There has been little or no research published on the process of implementing innovation within organisations allied to tourism, even though there have been calls in the innovation literature for this topic to be addressed (e.g. Carlborg et al., 2014; Choi \& Moon, 2014; Van de Ven et al., 2008).

Definitions of innovation vary but all note that 'As long as the idea is perceived as new to the people involved, it is an 'innovative idea', even though it may appear to others to be an 'imitation' of something that exists elsewhere' (Van de Ven et al., 2008: 9). The consequences of innovations may, therefore, represent no more than modest, or incremental, adaptations to practice (Hjalager, 2002). The implementation stage of the innovation process occurs when an innovation is introduced to the market, transferred to operating sites or diffused to potential adopters within, or external to, an organisation (Van de Ven et al., 2008). Implementation is, therefore, usually defined as the adoption of the innovation by 'users' both internally (staff) (Van de Ven et al., 2008) or externally (customers or suppliers) (Klein \& Sorra, 1996; Sawang \& Unsworth, 2011). Failure to implement successfully is not only intuitively problematic but has been shown to be detrimental to organisations in a variety of ways (e.g. Klein et al., 2001; Klein \& Knight, 2005; Pfeffer, 1994; Walker et al., 2002). Long-standing calls by public policy-makers for greater innovation in tourism are not likely to be fulfilled until this neglected but potentially decisive aspect is more fully understood. 
The prominent role interpersonal relationships play in shaping business practices generally is widely recognized but remains under theorized within the innovation and tourism specific literatures (Bornay-Barrachina et al., 2016; Noordin \& Karim, 2015; Sung and Choi, 2014). Behavioural issues were identified some time ago by commentators such as Mohamed (1995) and the impact of 'destructive' conflicts have been observed, inter alia, by McAdam (2005). However, a wider range of additional relational factors, such as the influence of power and hierarchy structures within organisations seeking to innovate, have received scant attention, notwithstanding their identification (Bruque \& Moyano, 2007).

The aim of the research reported in this paper was to analyze the role of interpersonal relationships in the implementation of innovation in modern music festivals in China. This involved the achievement of four objectives; to identify the range of interpersonal relationships within Chinese music festivals that affect the implementation of innovation; to interpret what influences the development of these relationships through the application of social exchange theory; to identify the range of outcomes of innovation implementation within these festivals; and to .provide a conceptual framework to explain the influences of interpersonal relationships on the outcomes of innovation implementation in the festival sector.

\section{CONCEPTUALISING THE IMPLEMENTATION PROCESS}

More than twenty years ago, Klein and Sorra (1996) proposed a model of innovation implementation that introduced notions of 'climate' and 'innovation-value fit'. The former refers to the extent to which employees perceive that their contribution to a specific innovation is expected, supported and rewarded within an organisation. Innovation-value fit is defined as 'the extent to which targeted users perceive that 
use of the innovation will foster (or, conversely, inhibit) the fulfilment of their values' (Klein \& Sorra, 1996: 1063). More recent studies have developed these ideas (e.g. Dong et al., 2008; Sawang \& Unsworth, 2011) resulting in six key factors that are broadly agreed as influencing and shaping the implementation process. These are: (1) implementation policies and practices, such as staff training, technology support, and a rewards systems; (2) perceptions of the importance of innovation implementation within the organisation; (3) the role of managers in fostering cultures and working practices conducive to implementation; (4) financial support; (5) the existence of a learning environment whereby on-going development leads to knowledgeable and motivated staff; and (6) managerial patience, which reflects a recognition of the time it takes to implement some innovations (Klein \& Knight, 2005). Many of these are likely to have specific challenges within the time constrained, volunteer reliant festival context.

Several commentators have drawn attention to the centrality of 'human resources' to effective implementation (e.g. Dooley et al., 2002; Sawang \& Unsworth, 2011; Starkweather, 2005) and in particular the role of front-line employees (Cadwallader et al., 2010; Hausman \& Stock, 2003; Van de Ven et al., 1989). Interpersonal communication is also highlighted as an enabling factor (Hausman \& Stock, 2003; Rapert et al., 2002) with socialization among staff encouraging the development of shared values (Bruque \& Moyano, 2007). Naturally, staff relations may also pose problems in terms of implementation as a result of user reluctance. Indeed, this has been found to have a greater negative impact on the implementation of innovation than technical and administrative problems (Nieves \& Segarra-Ciprés, 2015; Somech \& Drach-Zahavy, 2013). It is, therefore, appropriate to explore the extent to which the mix of paid workers, volunteers, private and public sector management 
found in the Chinese music festival sector share values and how these are created or otherwise through interpersonal communication.

The characteristics of particular innovations may also influence their implementation. Examples of these include the compatibility between the innovation and the company's existing values and practices; and the adaptability and flexibility of the innovation to the local context (Sung \& Choi, 2014; Venkatesh et al., 2003). Moreover, these characteristics may mediate the influence of individual competence and prior experience particularly on users' interaction with the innovation (Sung \& Choi, 2014).

Figure 1 summarizes the literature on a range of factors that have been identified as influencing the process of implementing innovations successfully. Clearly, not all factors will have the same level of influence. However, it provides a useful starting point for investigating the connections between interpersonal relationships and their potential mediating effect on factors influencing a festival organisation's ability to implement proposed innovations.

\section{[INSERT FIGURE 1 HERE]}

The potential longer term effects of approaches to implementing innovations have been described by Klein \& Sorra (1996). They argue that possible outcomes include effective implementation and enhanced organisation performance; effective implementation but no enhanced organisation performance; and a failure of implementation. Their study, does not, however, define 'effective implementation', or 'failure of implementation' and is somewhat imprecise on what would constitute enhanced organisational performance. It is perhaps more useful, therefore, to conceptualize potential outcomes along axes of stakeholder satisfaction and the 
efficiency of implementation. This allows for more nuanced outcomes to be considered which offers a useful means of understanding the connection between interpersonal relationships and the implementation of innovation.

The role of inter-personal relationships

It is widely accepted that inter-personal relationships influence the ability of employees to achieve their objectives generally (Hui et al., 2008; Liden et al., 2000; Love \& Forret, 2008; Seers et al., 1995) and this extends specifically to innovation (Erdogan \& Liden, 2002; Janssen \& Van Yperen, 2004; Liao et al., 2010; Martinaityte \& Sacramento, 2012; Volmer et al., 2012; Wilson et al., 2010). This study draws upon social exchange theory to examine the development of inter-personal relationships and how they influence the process of implementing innovations in a Chinese festival context. Social exchange theory focuses upon how a relationship is developed in terms of exchange rules and norms, exchange resources and motivations (Cook \& Whitmeyer, 1992; Cropanzano \& Mitchell, 2005; Foa \& Foa, 1974, 1980; Hui et al., 2008; Lawler \& Thye, 1999; Meeker, 1971; Molm, 1994, 2000, 2003) and is most useful in explaining the development or the basis of a relationship in depth (Cropanzano \& Mitchell, 2005; Love \& Forret, 2008). It has already been applied successfully in innovation studies (e.g. Liao et al., 2010; Martinaityte \& Sacramento, 2012; Shalley et al., 2004; Tierney \& Farmer, 2002), has been used to understand host/tourist relationships (e.g. Coulson \& MacLaren, 2014; Paraskevaidis \& Andriotis, 2017) and within event studies (e.g. Larson, 1997; Larson \& Wikström, 2001; Ziakas \& Costa, 2010). There is little research, as yet, that utilizes social exchange theory to explore the interpersonal relationships that influence innovation within tourism organisations. 
Social exchange theory emphasizes actors (individual or organisational), resources (material or symbolic), and relationships (direct or indirect, positive or negative) (Cook \& Whitmeyer, 1992; Cropanzano \& Mitchell, 2005; Molm, 2003). Key aspects of this conceptual framework include exchange rules and norms, motivation, resources and exchange relationships. 'Rules and norms of exchange are "the guidelines" of exchange processes' (Cropanzano \& Mitchell, 2005: 875) and include reciprocity as well as negotiation, rationality, altruism, group gain, status consistency, and competition (Cropanzano \& Mitchell, 2005; Meeker, 1971).

The cultural setting clearly has an influence on social exchanges and has been the subject of investigation by several academics (Cropanzano \& Mitchell, 2005; Parker, 1998; Rousseau \& Schalk, 2000; Shore \& Coyle-Shapiro, 2003). In China, guanxi is a culturally specific aspect of interpersonal relationships (Geddie et al., 2005; Li et al., 2007; Park \& Luo, 2001; Zhang \& Zhang, 2006). It may be viewed literally as 'connection', 'personal relationship networking' (Li et al., 2007: 116), or 'interpersonal ties' (Gu et al., 2008: 12). It has also been defined as 'special personal relationships' (Alston, 1989; Gold, 1985; Hackley \& Dong, 2001; Jacobs, 1979, 1982), social interactions based on continued or repeated exchanges of valued good or favor (Davies, 1995; Gold, 1985; Pye, 1982), or a special relationship developed between two actors, in which at least one needs something from the other (Osland, 1990). It has been argued that very different types of relationship are developed on the basis of guanxi (Fan, 2002). These can be categorized as: family guanxi, which is based on family or kinship; helper guanxi, which is usually related to interpersonal relationships between friends; and business guanxi, which are personal connections established and used by an intermediary. Some scholars sub-divide the latter into 
'business people to business people guanxi' and 'business people to government official guanxi' (Fan, 2002; Geddie et al., 2005). Guanxi can, therefore, be developed from social exchanges and, in turn, influence their development.

The impact of guanxi has already been noted in tourism and festival contexts. Li et al. (2007), for example, found that guanxi influenced community participation in tourism development in China. In the UK, guanxi was found to be influential in the organisation of Chinese New Year Festivals (Fu et al., 2014, 2015), and globally in the creation of social capital within the Chinese diaspora (Lew \& Wong, 2004).

Other studies have highlighted its impact on the adoption (or not) of CSR policies in the Chinese hotel industry (Gu et al., 2013) and the recognition of guanxi as the social mechanism in Chinese tourism governance (Zhao and Timothy, 2015). It would be remiss, therefore, to study the relationships involved in innovation implementation without considering the role of guanxi. The rules and norms of exchange, including guanxi, provide a theoretical basis for understanding how interpersonal relationships are developed in social exchanges. Particular rules and norms may lead to alternative exchange relationships (illustrated in Figure 2). For example, reciprocal exchanges influenced by a folk belief, a moral norm, or exchanges complying with altruism or group gain are said to lead, generally, to positive interpersonal relationships (Cropanzano \& Mitchell, 2005; Molm, 2000, 2003). Unequal negotiated exchanges and exchanges complying with competition, however, are more likely to result in negative relationships (Molm, 2003).

\section{[INSERT FIGURE 2 HERE]}

Different cultures tend to apply diverse combinations of exchange rules in social activities (Benedict, 1935; Mead, 1937; Meeker, 1971). In individualistic Western 
cultures, friendships usually comply with reciprocity and status consistency between equals, business relations are perceived as being based on rationality and relationships in bureaucracies typically comply with status consistency between unequal statuses (Meeker, 1971). Conversely, in Eastern collectivist cultures, complying with group gain is more common (Parsons, 1951). In China, where people are more oriented towards collectivism (Leung, 1997; Triandis, 1990; Triandis et al., 1990), they may consider respect, face giving, and interpersonal harmony or relationship harmony as most important when developing interpersonal relationships (Ding, 1995; Hui et al., 2008; Jehn \& Weldon, 1992). Also, influenced by the Confucian culture, there is a greater emphasis on harmonious relationships through controlling emotions and working cooperatively (Chan, 1963; Hui et al., 2008). Thus, it may be assumed that, in China, people are more likely to comply with reciprocity as a folk belief or a moral norm, status consistency, or group gain, rather than competition in order to cultivate and maintain harmonious interpersonal relationships. It is unlikely, therefore, that relationship development and its impact on innovation implementation within China will mirror findings in other individualistic cultures.

Within innovation studies, the application of social exchange theory has identified positive associations between constructive leader/member exchanges and the generation or implementation of innovations (Liao et al., 2010; Martinaityte \& Sacramento, 2012; Volmer et al., 2012), as well as between team/member exchanges and staff creativity (Liao et al., 2010). Strong leader/member relationships encourage the acquisition of essential tangible and intangible resources needed in the implementation of individual innovation and the motivation for action (Dansereau et al., 1975; Graen \& Scandura, 1987; Martinaityte \& Sacramento, 2012; Wilson et al., 2010). 
The research reported in the remainder of the paper sought to answer four questions: what were the important relationships during the implementation of innovations in music festivals? How did these relationships develop? What influence did these relationships have on the implementation of innovations in the music festivals? What specifically Chinese contextual factors (political, social, or cultural) influenced the relationships and the implementation of innovation?

\section{RESEARCH DESIGN AND METHODS}

A qualitative multi-method approach was taken using the main data gathering tools of in-depth semi-structured interviews and participant observation over a six-month time period.

The six purposively selected music festivals represent a mix of regional and national modern music festivals in mainland China including some located in the north, the east, the south and the mid-west. The background of each is introduced briefly in Table 1 below. In order to maintain confidentiality, the names of the festivals have been replaced with case numbers.

\section{[INSERT TABLE 1 HERE]}

Table 2 summarizes the methods used in each case study. These consisted of indepth semi-structured interviews with key actors, direct observations of the environment, activities and participants at the six music festivals, participant observation (one of the researchers worked as a staff member or volunteer at each festival), observation of participants' discussions in their online groups, and observation of participants' use of Weibo (similar to Twitter). Collectively, the intention was to gain a balanced perspective of how innovations were implemented, 
how relationships developed and how they influenced the implementation of innovations within these music festivals.

\section{[INSERT TABLE 2 HERE]}

The first phase of data collection consisted of direct and participant observation relating to innovation implementation. The descriptive observational data gathered were then developed into a narrative account (Saunders et al., 2007) of what happened during the implementation stage. This enabled identification of who to interview and the preliminary lines of enquiry to pursue. They also served as a mechanism for data triangulation.

The second stage involved interviewing key actors (see Table 3). The chosen festivals were found to be rich in innovation implementation data resulting in 128 interviews. These provided information about the social and organisational context, perspectives on various inter-personal relationships (focused on how these affected the process of implementation) and the outcomes of innovation implementation.

\section{[INSERT TABLE 3 HERE]}

Interviews were conducted face to face, via telephone, or QQ voice call (a Skypetype platform) in Mandarin or Cantonese dependent upon the preference of the participant. The interviews took place during or soon after the festival. The length of interview was tailored to the experience of the participant with most lasting approximately one hour and some taking as long as three hours.

All audio records of interviews and field notes from the observation were firstly transcribed in the original language. A five step process was then followed to analyse the transcribed data: data reduction, categorization, 'unitizing' data, 
recognizing relationships between different emerging themes, building up interpretations and theory (Guest et al., 2012; Holloway, 1997; Miles \& Huberman, 1994; Saunders et al., 2007). The data were 'reduced' by eliminating material that did not relate to the research questions. In the categorization process, quotations and other content were coded and classified into different themes. Following categorization, the data were unitized or clustered to explore the relationships between themes. Finally, after clarifying all relationships between themes and different groups of evidence (Guest et al., 2012), the data were interpreted to address the research questions.

\section{THE IMPLEMENTION OF INNOVATION IN CHINESE MUSIC FESTIVALS}

In total, eleven innovations were identified and discussed with participants. These are summarized in Table 4 which gives an overview of the type of innovation, the actors involved and the main features of the implementation. Innovations were a combination of radical and incremental, encompassing product, process and managerial/organisational innovations; all were new to the festival in which they were observed.

\section{[INSERT TABLE 4 HERE]}

The remainder of the paper discusses the implementation outcomes and the relationships (and influences on those relationships) that affected them.

\subsection{Innovation Implementation Outcomes}

In order to interpret the data, four potential innovation outcomes were identified. When the implementation consumed minimal or expected resources, the implementation process was categorized as efficient. When it consumed additional 
resources to those planned, it was deemed inefficient. The consequences of the innovation in terms of stakeholder satisfaction were classified as minor if limited to the innovation itself and major if it affected other parts of the festival. Combining these two factors results in the four possible implementation outcomes. For example, the outcome 'satisfied stakeholder and efficient process' indicates that key stakeholders received the expected benefits from the innovation and the process of delivering the innovation consumed only the expected resources. The outcome of 'satisfied stakeholder and inefficient process' occurs when stakeholders received the expected benefits but the implementation process was not efficient. 'Dissatisfied stakeholder and minor consequence' indicates that problems occurred during the implementation process and this hampered the delivery of expected benefits or value to key stakeholders. 'Dissatisfied stakeholder and major consequence' indicates that problems occurred during the implementation process that affected the benefits to stakeholders and caused negative consequences to the innovation as well as to the staging of the festival. Table 5 summarizes the implementation outcomes of all eleven innovations in the six music festivals and the relationships that influenced them. By way of illustration, the implementation outcome of 'dissatisfied stakeholder and major consequence' occurred in the implementation of three innovations, i.e. Imart (Festival 1), campsite (Festival 2), and campsite (Festival 6).

[INSERT TABLE 5 HERE] 


\subsection{The development of relationships}

Relationships formed an important aspect of participants' explanations of what made for successful and less successful implementation outcomes. It is well documented that exchange rules and norms are important influences on relationship development (Cropanzano \& Mitchell, 2005; Meeker, 1971; Molm, 2000, 2003). In this case, this was most conspicuous among volunteers. The particular rules and norms tended to emphasize notions of altruism and reciprocity. To a large extent, this confirms the Chinese cultural emphasis on altruism as the core value for any volunteering (Earley, 1989; Yu et al., 2013) and the notion of 'reciprocal altruism' identified by

Paraskevaidis \& Andriotis (2017). The following comments from volunteers involved in two different innovations illustrate these observations:

'I really think that this is a selfless devotion.'

'As we were volunteering we would definitely help others when we saw they were in need.'

'I think, because it was volunteering I was trying my best to do something for others. This made me feel very good'.

Altruism encouraged volunteers to create supportive networks which helped them implement several of the innovations. The perceived 'cost' of their altruistic exchange was low because of the inevitably short-term nature of their engagement with festivals. Not surprisingly, altruism was not associated with staff other than volunteers.

Some commentators have argued that the temporary nature of planned events means that staff are less familiar with each other, and that this limits the extent to 
which socio-emotional resources, such as commitment and trust, are exchanged (Larson, 1997; Larson \& Wikström, 2001). The suggestion is, therefore, that positive relationships become more difficult to develop in these contexts (Larson, 1997). The findings of this project suggest that this issue may be mediated by volunteers' altruistic behaviour which, in turn, overcomes the potential lack of staff commitment and trust.

\subsection{Exchange resources}

The literature suggests that socio-emotional resources such as love, respect and feeling valued are more likely to result in positive and long-term exchange relationships than concrete economic resources (e.g. money, goods, information, and service) (Cropanzano \& Mitchell, 2005; Foa \& Foa, 1974, 1980; Shore et al., 2001). This is consistent with the analysis of relationships found within each of the six cases studied. For example, the implementation of 'festival representatives' (staff with the role of running warm-up activities on the stages and helping to promote the festival partners) which was introduced as an innovation by Festival 2, involved performing on stage as a mutually-reliant group. Comments from participants illustrate the importance to them of the socio-emotional resource exchanges that evidently went on:

'It was the power of affection. I felt if they didn't care about us or guide us, we would be like a bunch of isolated rocks; however, it was because they gave us this spiritual support, I felt we were connected together, and then our working efficiency was increased.'

'Anyway, it was because of this affection. At the beginning I really wanted to quit. Then one night I talked to my supervisor and then I felt that everybody 
was very concerned about us. If I quit, it would be too irresponsible and too bad, so I stayed at the job.'

Not all relationships were harmonious. The data from music festivals 1, 2, 3, 4 and 5 show that some were characterized by conflict due to the lack of exchange of socioemotional resources:

'The essential problem is that they did not give us enough respect. This is what I think.'

'Being a volunteer should mean doing the job with full attention; however, because they didn't fully respect and value us, I felt like I didn't fully value the work and didn't pay full attention to the work.'

The provision of material benefits to volunteers influenced how relationships developed, tending to result in positive or harmonious relationships. The implementation of a new volunteer management system for Festival 5 provides a useful illustration. The festival outsourced its recruitment and volunteer management function for the first time. As shown below, the benefits provided by having an independent professional management organisation in charge of volunteer recruitment and management appeared to encourage the development of harmonious relationships:

'At least when we had a break, they had prepared everything for me. Drinks, food, were all prepared.'

'The manager was quite nice to us, and there were some small benefits, such as they got us some drinks or some food, etc. and I felt that was quite considerate in every aspect and treated us quite well.' 
'Those traders were quite nice to us volunteers. And they gave all of us a small gift.'

Where these did not exist, there were negative consequences:

'We felt like if they could provide us with better equipment, or something in material value we would definitely work better.'

'It was not my obligation and responsibility to obey you. I did not receive a penny from you. I did not get paid to work for you.'

The conflicted relationships illustrated here became dysfunctional and led to subtle actions, such as the withdrawal of goodwill, which subverted the implementation of the innovation. In the case of Festival 1, it also appeared to precipitate a withdrawal of voluntary labor (a strike) which also threatened to undermine the innovation. This, albeit extreme case, provides valuable insight and is used to illustrate the dynamics of exchange resources also found elsewhere.

Although the literature suggests that exchanging economic resources is less influential than exchanging socio-emotional resources (Cropanzano \& Mitchell, 2005), the findings suggest a more nuanced effect on relationship development. Indeed, the boundary between the economic and the socio-emotional appears to be less distinct than presented by some and the connection between the two more complicated in social exchanges within events that are dependent upon volunteer labor. Part of this complexity arises from the unfamiliarity between volunteers because of the temporary nature of festival volunteering. In these circumstances, socio-emotional exchange resources, such as commitment and trust, have less time to develop and, therefore, less time to create positive interpersonal relationships 
(Larson, 1997; Larson \& Wikström, 2001; Ziakas \& Costa, 2010). A comment from a campsite director on the difficulties caused by having to recruit staff quickly and locally illustrates the point:

'But I had no choice. I can only recruit most of the staff after arriving at the festival host location. I cannot bring temporary staff from home to the host city. The cost is too high if I keep them for long-term. I can't do this'.

The Chinese socio-cultural context also influences the manner in which relationships develop amongst volunteers. Although the literature often draws attention to the emphasis given to actions that lead to harmonious relationships within a Chinese context (Ding, 1995; Hui et al., 2008; Jehn \& Weldon, 1992), as with any broad characterization, this runs the danger of stereotyping. The interview data revealed the importance of material benefits as a measure of gain and loss for several members of the working staff and volunteers during their exchanges. As the importance of money and material possessions grows, the importance of socioemotional feelings seems to be diminishing (e.g. Lee \& Guo, 2008; Li \& Wood, 2016).

The importance of the Chinese cultural context also appeared to be reflected in how research subjects perceived corruption. In the implementation of I-mart (Festival 1), there were severe conflicts between the I-mart volunteers and local government officers who were responsible for the recruitment and management of the volunteers. The findings reveal the disquiet of volunteers:

'An officer from the government said that there were indeed outdoor jackets, however, they were all handed out to government officers earlier. Those were 
our outdoor jackets. Each of the government officers got forty outdoor jackets (raised voice, angry tone) '.

'The only benefit we had were the outdoor jackets; however the government took them from us [raised voice, angry tone]'.

'The main thing the government was keen on doing was to take our outdoor jackets. They planned it.'

The expectation of corruption within officialdom in this context, whether justified or not, triggered negative reactions to the local municipal authority. In these circumstances, the volunteers were more likely to consider themselves victims of an unequal exchange than contributors to a meaningful and innovative project.

Interpersonal relationships developed on the basis of guanxi (Fan, 2002) were also a potential source of conflict within social exchanges. For example, the I-mart manager assigned the good positions (stalls) to those traders with whom they had 'helper' guanxi (i.e. relationships developed between friends (Fan, 2002), and the worse positions to other traders with whom they had no guanxi. The evident dissatisfaction among a significant component of this constituency threatened the impact of the innovation.

Rather less predictably, guanxi based on friendships also resulted in problems in the implementation of I-mart. This was exacerbated when the manager needed to expel unauthorized traders from the festival but failed to do so due to guanxi with some of them. The unauthorized traders caused problems for the operation of the whole festival as well as the implementation of I-mart. As one of the managers made clear: 
'We met a lot of problems in the action of expelling the unauthorized traders. It was because many of the unauthorized traders were friends of mine. They asked whether it was me who was expelling the unauthorized traders. I said yes. Then they said, "So just don't kick me out".'

A sense of reciprocity among actors was an essential feature of positive social exchange relationships, notably where volunteers were motivated by notions of altruism. This provides further confirmation that exchange rules and norms conflated to influence actors' exchange behaviour and the development of their exchange relationships.

The findings reveal that both exchange rules and norms and exchange resources influence the development of relationships within the innovation implementation processes. The relationships can be categorized in two ways. Firstly, according to whether people 'got on well with each other' without obvious conflicts i.e. whether relationships were harmonious or conflicted. Secondly, whether their relationships helped them to accomplish their duties or hindered them i.e. whether they were functional or dysfunctional (McAdam, 2005). This leads to the identification of four types of relationship within this context: harmonious-functional, harmoniousdysfunctional, conflicting-dysfunctional, and conflicting-functional.

The harmonious-dysfunctional relationships shown in the data were mainly friendships or those that incorporated significant guanxi. In these cases, harmoniousdysfunctional relationships tended to make use of their positive friendships or guanxi to satisfy their personal purposes rather than to accomplish organisational objectives. As one of the traders pointed out: 
'Those people who had good personal relationships certainly got better positions, while those who had normal relationships certainly got appointed randomly.'

Conflicting-dysfunctional relationships were apparent when people did not get on well with each other and that relationship hindered the accomplishment of their duties. The strike by volunteers at Festival 1 as a result of a breakdown in the relationship with management (in implementing the new market) highlights this:

'During this year, the volunteers' benefits were worse than in previous years, so everybody felt unhappy about this. Then all of us went on strike together.'

'When it was raining, we had no protection at all. We couldn't work for them while getting wet in the rain and work hard. During that time we stayed wherever it was warm and dry, somewhere quiet where we could talk, eat, drink, and play because nobody cared about us. In this case will we still work for them? No way. So we protected ourselves'.

Conflicting-functional relationships occurred when negative relationships did not detrimentally affect their duties. In several cases, conflicting-functional relationships tended to create more pressure which in turn led to greater attention to their work, as they felt they could not trust or rely on others. For example, during the I-mart innovation implementation the relationship between staff and the electrical subcontractors broke down. The I-mart staff lost confidence in the electricity supply officers and, therefore, paid closer attention to monitoring their work. Although their relationship was conflicted, this resulted in the accomplishment of the task i.e. the lighting and electricity in I-mart was set up before I-mart opened to the public. 


\section{THEORIZING THE ROLE OF RELATIONSHIPS ON THE IMPLEMENTATION OF INNOVATION IN EVENTS}

This research project has revealed a set of inter-related relational factors that influence the ability of organisations to implement proposed innovations in Chinese modern music festivals. A conceptual framework (Figure 3) helps explain how these are combined processionally to influence innovation implementation outcomes. Informed by the premises of social exchange theory and data gathered from the specific festival contexts, the upper half of the framework helps explain relationship development. Exchange rules and norms and exchange resources were found to be highly influential in actor exchanges. In practice, their effects were complex with some inter-dependency; the impact of resource exchange issues were mediated by the exchange rules and norms complied with and, conversely, the exchange rules and norms applied within the relationships were affected by the types and amounts of resources exchanged. Nevertheless, the analytical simplification or abstraction is useful because it highlights what were empirically dominant themes.

\section{[INSERT FIGURE 3 HERE]}

Five factors that influence compliance with particular exchange rules and norms, the motivation to exchange resources, and the type and amount of resources exchanged were also identified. These were identity, equality, social capital, event context, and social-cultural context. In particular, identifying oneself as 'volunteer' led to a greater emphasis on altruism, which encouraged the development of harmonious relationships, and subsequently, enhanced the acquisition and use of resources 
during the implementation. Equality, guanxi, the peculiarities of the event and the socio-cultural context all influenced the motivation to exchange resources, and the type and amount of resources exchanged.

A positive-negative classification has been widely used to analyse social exchange relationships at the workplace (e.g. Cropanzano \& Mitchell, 2005; Eisenberger et al., 1986, 1990; Liao et al., 2010; Martinaityte \& Sacramento, 2012; Robinson et al., 1994; Settoon et al., 1996; Tierney, 1992). However, the findings here indicate that relationships within the innovation implementation process are more nuanced than this and that the function of a relationship, in terms of helping to achieve tasks in the workplace, is also important. The framework illustrates four relationship types as identified earlier.

Expanding the theoretical framework developed in previous studies (e.g. Dong et al., 2008; Hjalager, 2010; Sawang \& Unsworth, 2011), the final section of the framework shows how these four relationship types are connected to the outcome of innovation implementation by influencing the acquisition, and/or use of knowledge and other resources necessary within the implementation process.

Four types of innovation implementation outcome were observed based on three aspects: stakeholder satisfaction, efficiency of process, and level of consequence. These are important dimensions because they collectively indicate the value added arising from a successful innovation process (Schumpeter, 2000; Tidd \& Bessant, 2009) and are worthy of further discussion in relation to resource utilization.

A predictable input of knowledge and resources (e.g. time, labor power, and materials) is seen as an efficient process of implementation whereas unexpected (additional) input indicates an inefficient process. By definition, when key 
stakeholders are dissatisfied they do not gain the expected benefits of the innovation. If the negative consequences are limited to the innovation itself without affecting other parts of the festival, they are categorized within the framework as minor. When there are consequences to other parts of the festival, they are considered major. To illustrate, in one case the problem of unauthorized traders affected the entire festival, causing health and safety problems in the festival arena and prompting complaints from sponsors. The consequences to stakeholders were, therefore, major.

The way in which the four types of relationships influence the four types of innovation implementation outcome is predictably complex. Harmonious and functional relationships encourage, but do not guarantee, a successful implementation process. Conflicting and dysfunctional relationships inhibit the implementation of innovation from being successful but do not necessarily lead to implementation failure. Although harmonious and functional relationships have some positive influence on the implementation of innovations, conflicting and dysfunctional relationships are, generally, found to be more influential.

Harmonious and functional relationships are important in ensuring the efficient and successful use of knowledge and other resources in order to provide what is needed for the implementation of an innovation. In this situation, the innovation is implemented fully and provides the expected value to innovation adopters or key stakeholders. Furthermore, the implementation process is efficient as the resources invested in implementing the innovation are within budget. .These conditions were exemplified by the case of a complaints center created by Festival 5. 
Harmonious relationships do not, however, guarantee success. In some cases they hamper the implementation of innovations. . This is especially so when harmonious relationships are turned into guanxi. These harmonious-dysfunctional relationships were seen to negatively affect both the implementation of the innovation (minor consequence) and other aspects of the festival (major consequence). In Festival 1, for example, the harmonious relationships between the manager and his unauthorized trader friends (guanxi) prevented him from expelling them. This resulted in complaints and dissatisfaction amongst official I-mart traders as well as causing health and safety problems and damaging sponsorship agreements.

Conflicting-dysfunctional and conflicting-functional relationships inhibit the actors' willingness, motivation, and efficiency to apply the knowledge and resources they possess to the implementation process. Although these conflicting relationships inhibit successful implementation, they do not necessarily lead to failure but they do create a need for additional resources and, consequently, reduce the efficiency of implementation.

Perhaps surprisingly, it is the conflicting or dysfunctional relationships that are the most influential. Although harmonious or functional relationships aid the acquisition and use of knowledge and resources essential for implementation, conflicting or dysfunctional relationships are 'out of the ordinary' and when they occur they have a more marked negative effect.

The implementation of innovation is a complex process that consists of various relationships. It is clear that there is a combination of factors influencing the development of relationships. Four types have been identified by this study, each having a differential impact on the innovation implementation process. As 
harmonious relationships do not necessarily result in successful implementation, an important managerial implication of this study is its highlighting of the need to prevent conflict and damaging harmonious but dysfunctional relationships which disproportionately hinder innovation implementation.

\section{CONCLUSION}

The tourism and innovation literatures have tended not to problematize the process of implementing innovation, paying most attention instead to organisational capabilities, innovation systems and processes. The typology of innovation implementation developed as a result of the research reported in this paper demonstrates the limitations of current theory. Aspects of social exchange theory have been shown to be valuable ways of interpreting the development of relationships and their consequences for the implementation process.

The festival context undoubtedly plays a role in the development of relationships (Larson \& Wikström, 2001; Ziakas \& Costa, 2010) and influences the implementation of innovations. Innovations are usually implemented by temporary staff or volunteers who are less likely to exchange socio-emotional resources such as commitment and trust. In such a temporary situation, economic resources can become more important in individuals' social exchanges, and there are fewer opportunities for individuals to develop harmonious relationships. In addition, innovations have to be implemented within a shorter period and, therefore, staff and volunteers have less time to solve any problems caused by conflicting relationships.

It is important to recognize the importance of the Chinese socio-cultural context. Some factors identified in the development of relationships, such as altruism and guanxi, are often seen as characteristic or culturally defining values (Dubs, 1951; 
Horioka, 2010). The identity construction of volunteers is also specific to the Chinese context which strongly connects volunteerism with the notion of altruism and portrays volunteerism as 'glorious' behaviour (Ding, 1999; Earley, 1989; Han, 2009; Jiang, 2007; Lai et al., 2013; Law \& Shek, 2009; Yu et al., 2013; Yuan \& Tan, 2011; Zhang \& Lin, 2008; Zhuang, 2010). The growing sense of materialism exhibited in some of the case studies and documented in the wider literature (Lee \& Guo, 2008; Li \& Wood, 2016), however, suggests that this should not be exaggerated. This has implications for how workers (both paid and unpaid) will want to be rewarded for their role in the implementation of innovations.

Most accounts of relationship development using social exchange theory suggest that economic resources are less influential than socio-emotional resources in the development of positive exchange relationships (Cropanzano \& Mitchell, 2005; Foa \& Foa, 1974, 1980; Shore et al., 2001). This study has shown that the boundary between economic resources and socio-emotional resources was found to be less distinct in that economic resources could replace socio-emotional resources, or have the same or similar impact (e.g. exchanging economic resources such as money or goods is seen as a form of exchanging respect, a socio-emotional resource, in the context studied). The findings also show that a lack of economic resources can cause significant conflict between actors and, subsequently, their conflicting relationships lead to the failure to implement innovations successfully. It is difficult to conclude that socio-emotional resources are more influential than economic resources in developing positive relationships because even when people exchange socio-emotional resources, the lack of economic resources might also result in a negative relationship. In addition, when people do not exchange socio-emotional resources, the adequate exchange of economic resources might also result in a 
positive relationship. This indicates that it is difficult to define the type of exchange resources that is better for developing positive relationships at festivals.

Exchange relationships are often seen as either positive or negative in studies of social exchange (Cropanzano \& Mitchell, 2005; Eisenberger et al., 2004; Foa \& Foa, 1974, 1980; Molm, 2000, 2003; Shore et al., 2001). This research provides a more nuanced analysis for understanding exchange relationships within certain organisational settings. A starting point of using two dimensions (harmonious vs conflicting, functional vs dysfunctional) leads to four types of exchange relationship within the context of innovation implementation in events.

The conceptual framework developed in this paper reveals the complex manner in which relationships impact upon plans to innovate and enriches understanding of innovation by developing a categorization of interpersonal relationships that affect the implementation of innovation. This provides researchers with a valuable approach to examining related aspects of the innovation process as well as the implementation of innovation in contrasting contexts.

\section{REFERENCES}

Alston, J. P. (1989). Wa, Guanxi, and Inhwa: Managerial Principles in Japan, China, and Korea. Business Horizons, 32(2), 26-31.

Axtell, C. M., Holman, D. J., Unsworth, K. L., Wall, T. D., Waterson, P. E., \& Harrington, E. (2000). Shopfloor Innovation: Facilitating The Suggestion and Implementation of Ideas. Journal of Occupational and Organizational Psychology, 73,265-285.

Benedict, R. (1935). Patterns of Culture. Boston and New York: Houghton Mifflin.

Bornay-Barrachina, M., López-Cabrales, A., \& Valle-Cabrera, R. (2016). How Do Employment Relationships Enhance Firm Innovation? The Role of Human and Social Capital. The International Journal of Human Resource Management, 1-29. 
Brooker, E., \& Joppe, M. (2014). Developing a Tourism Innovation Typology: Leveraging Liminal Insights. Journal of Travel Research, 53(4), 500-508.

Bruque, S., \& Moyano, J. (2007). Organizational Determinants of Information Technology Adoption and Implementation in SMEs: The Case of Family and Cooperative Firms. Technovation, 27, 241-253.

Cadwallader, S., Jarvis, C.B., Bitner, M.J., \& Ostrom, A.L. (2010). Frontline Employee Motivation to Participate in Service Innovation Implementation. Journal of the Academy of Marketing Science, 38, 219-239.

Carlborg,P., Kindstrom, D., \& Kowalkowski, C. (2014). The Evolution of Service Innovation Research: A Critical Review and Synthesis. The Service Industries Journal, 34(5), 373-398.

Carlisle, S., Kunc, M., Jones, E., \& Tiffin, S. (2013). Supporting Innovation for Tourism Development Through Multi-Stakeholder Approaches: Experiences from Africa. Tourism Management, 35, 59-69.

Carlsen, J., Andersson, T.D., Ali-Knight, J., Jaeger, K., \& Taylor, R. (2010). Festival Management Innovation and Failure. International Journal of Event and Festival Management, 1(2), 120 - 131.

Carmisón, C., \& Monfort-Mir, V.M. (2012). Measuring Innovation in Tourism from the Schumpeterian and the Dynamic-Capabilities Perspectives. Tourism Management, 33(4), 776-789.

Chan, W.T. (1963). A Source Book in Chinese Philosophy. Princeton: Princeton University Press.

Choi, J.N., \& Moon, W.J. 2014. Multiple Forms of Innovation Implementation: The Role of Innovation, Individuals, and the Implementation Context. Organizational Dynamics, 42, 290-297.

Cook, K.S., \& Whitmeyer, J.M. (1992). Two Approaches to Social Structure: Exchange Theory and Network Analysis. Annual Review of Sociology, 18, 109-127.

Cropanzano, R., \& Mitchell, M.S. (2005). Social Exchange Theory: An Interdisciplinary Review. Journal of Management, 31(6), 874-900.

Coulson, A. B., MacLaren, A. C., McKenzie, S., \& O'Gorman, K. D. (2014). Hospitality codes and Social Exchange Theory: The Pashtunwali and tourism in Afghanistan. Tourism Management, 45, 134-141.

Czernek, K. (2017). Tourism features as determinants of knowledge transfer in the process of tourist cooperation. Current Issues in Tourism, 20(2), 204-220.

Dansereau, F., Graen, G., \& Haga, W. J. (1975). Vertical Dyad Linkage Approach to Leadership Within Formal Organizations: Longitudinal Investigation Of Role Making Process. Organizational Behavior and Human Performance, 13, 46-78.

Davies, H. (1995). China Business: Context and Issues. Hong Kong: Longman Asia Ltd. 
Ding, D. Z. (1995). In Search Of Determinants of Chinese Conflict Management Styles In Joint Ventures: An Integrated Approach. Paper presented at the Thirteenth Annual Conference of the Association of Management, August, in Vancouver, Canada.

Ding, Z. (1999). Zhiyuan jingsheng zai zhongguo [Volunteerism in China]. Beijing, China: United Nations Volunteers-United Nations Development Programme.

Dong, L., Neufeld, D.J., \& Higgins, C. (2008). Testing Klein and Sorra's Innovation Implementation Model: An Empirical Examination. Journal of Engineering Technology Management, 25, 237-255.

Dooley, K.J., Subra, A., \& Anderson, J. (2002). Adoption Rates and Patterns of Best Practices in New Product Development. International Journal of Innovation Management, 6(1), 85-103.

Dubs, H. H. (1951). The Development of Altruism in Confucianism. Philosophy East and West, 1(1), 48-55.

Earley, P.C. (1989). Social Loafing And Collectivism: A Comparison of the United States and the People's Republic of China. Administrative Science Quarterly, 34(4), 565-581.

Eisenberger, R., Fasolo, P., \& Davis-LaMastro, V. (19900. Perceived Organizational Support and Employee Diligence, Commitment, and Innovation. Journal of Applied Psychology, 75, 51-59.

Eisenberger, R., Huntington, R., Hutchison, S., \& Sowa, D. (1986). Perceived Organizational Support. Journal of Applied Psychology, 71, 500-507.

Eisenberger, R., Lynch, P., Aselage, J., \& Rohdieck, S. (2004). Who Takes The Most Revenge? Individual Differences in Negative Reciprocity Norm Endorsement. Personality \& Social Psychology Bulletin, 30, 789-799.

Erdogan, B., \& Liden, R. C. (2002). Social Exchanges in the Workplace: A Review of Recent Development and Future Research Directions in Leader-Member Exchange Theory. In: Neider, L. L., \& Schriesheim, C. A. eds. Leadership. Greenwich, CT: Information Age Publishing, 65-114.

Fan, Y. (2002). Questioning Guanxi: Classification and Implications. International Business Review, 11, 543-561.

Foa, U.G., \& Foa, E.B. (1974). Societal Structures of the Mind. Springfield: Charles C Thomas.

Foa, U.G., \& Foa, E.B. (1980). Resource Theory: Interpersonal Behavior as Exchange. In: Gergen, K.J., Greenberg, M.S., \& Willis, R. H. eds. Social exchange: Advances in Theory and Research. New York: Plenum.

Fu, Y., Long, P., \& Thomas, R. (2014) Guanxi and the organisation of Chinese New Year festivals in England. Event Management, 18(3), 247-263. 
Fu, Y., Long, P., \& Thomas, R. (2015) Diaspora community festivals and tourism. In: Newbold, C., Maughan, C., Jordan, J., \& Bianchini, F. (Eds) Focus on festivals: Contemporary European case studies and perspectives. Oxford: Goodfellow Publishers, 201-213.

Geddie, M.W., Defranco, A.L., \& Geddie, M.F. (2005). A Comparison of Relationship Marketing and Guanxi: Its Implications for the Hospitality Industry. International Journal of Contemporary Hospitality Management, 17(7), 614-632.

Getz, D., \& Page, S.J. (2016). Progress and prospects for event tourism research. Tourism Management, 52, 593-631.

Gold, T. B. (1985). After Comradeship: Personal Relations in China Since The Cultural Revolution. The China Quarterly, 104, 657-675.

Graen, G. B., \& Scandura, T. A. (1987). Toward A Psychology of Dyadic Organizing. Research in Organizational Behavior, 9, 175-208.

Gu, F.F., Hung, K., \& Tse, D.K. (2008). When Does Guanxi Matter? Issues of Capitalization and Its Dark Sides. Journal of Marketing, 72, 12-28.

Gu, H., Ryan, C., Bin, L., \& Wei, G. (2013). Political connections, guanxi and adoption of CSR policies in the Chinese hotel industry: Is there a link? Tourism Management, 34, 231-235.

Guest, G., Macqueen, K.M., \& Namey, E.E. (2012). Applied Thematic Analysis. London: SAGE Publication, Inc.

Hackley, C. A., \& Dong, Q. (2001). American Public Relations Networking Encounters China's Guanxi. Public Relations Quarterly, 46,16-19.

Hall, C.M. (2009). Innovation and Tourism Policy in Australia and New Zealand: Never The Twain Shall Meet? Journal of Policy Research in Tourism, Leisure and Events, 1(1), 2-18.

Hall, C. M., \& Williams, A. M. (2008). Tourism and Innovation. London: Routledge. Hamdani, J., \& Wirawan, C. (2012). Open Innovation Implementation to Sustain Indonesian SMEs. Procedia Economics and Finance, 4, 223-233.

Han, Y. (2009). Research on Voluntary Services in China. Asian Social Science, 5(4), 86.

Hausmana, A., \& Stock, J.R. (2003). Adoption and Implementation of Technological Innovations within Long-Term Relationships. Journal of Business Research, 56, $681-686$.

Hjalager, A.-M. (2002). Repairing innovation defectiveness in tourism. Tourism Management, 23, 465-474.

Hjalager, A.-M. (2010). A Review of Innovation Research in Tourism. Tourism Management, 31, 1-12. 
Hjalager, A-M. (2015). 100 Innovations That Transformed Tourism. Journal of Travel Research, 54(1), 3-21.

Holloway, I. (1997). Basic Concepts for Qualitative Research. London: Blackwell Science Ltd.

Horioka, C. Y. (2010). An International Comparison of Altruism and Bequest Motives: The Case of China, India, Japan, and the United States. Institute Of Social and Economic Research, Osaka University.

Hui, C., Law, K.S., Chen, N.Y.F., \& Tjosvold, D. (2008). The Role of Co-Operation and Competition on Leader-Member Exchange and Extra-Role Performance in China. Asia Pacific Journal of Human Resources, 46(2), 133-152.

Jacobs, J. B. (1979). A Preliminary Model of Particularistic Ties in Chinese Political Alliances: Kan-Chi'ing and Kuan-Hsi in a Rural Taiwanese Township. The China Quarterly, 78, 237-273.

Jacobs, J. B. (1982). The Concept of Guanxi and Local Politics in a Rural Chinese Cultural Setting. In: Greenblatt, S. L., Wilson, R. W. \& Wilson, A. A. Eds. Social Interaction in Chinese Society. New York:Praeger: 209-236.

Janssen, O., \& Van Yperen, N. W. (2004). Employees' Goal Orientations, the Quality of Leader-Member Exchange, and the Outcomes of Job Performance and Job Satisfaction. Academy of Management Journal, 47, 368-384.

Jehn, K., \& Weldon, E. (1992). A Comparative Study of Managerial Attitudes toward Conflict in the United States and the People's Republic of China: Issues of Theory and Measurement. Paper Presented At the Academy of Management, August, In Las Vegas, NV.

Jiang, X. Q. (2007). Volunteerism in China: Development, Issues and Trends. Volunteering Service in China, 99-150.

Klein, K.J., \& Knight, A.P. (2005). Innovation Implementation: Overcoming the Challenge. Current Directions in Psychological Science, 14(5), 243-246.

Klein, K.J., \& Sorra, J.S. (1996). The Challenge of Innovation Implementation. Academy of Management Review, 21(4), 1055-1080.

Klein, K.J., Conn, A.B., \& Sorra, J.S. (2001). Implementing Computerized Technology: An Organization Analysis. Journal of Applied Psychology, 86(5), 811824.

Krizaj, D. Brodnik, A., \& Bukovec, B. (2014). A Tool for Measurement of Innovation Newness and Adoption in Tourism Firms. International Journal of Tourism Research, 16(2), 113-125.

Lai, M. H., Ren, M. Y., Wu, A., \& Hung, E. P. (2013). Motivation as mediator between national identity and intention to volunteer. Journal of Community \& Applied Social Psychology, 23(2), 128-142. 
Larson, M. (1997). Evenemangsmarknadsföring-Organisering, Styrning Och Samverkan Vid Marknadsföringen Av VM I Friidrott 1995. Östersund, Tryckeribolaget Östersund AB.

Larson, M., \& Wikström, E. (2001). Organizing Events: Managing Conflict and Consensus in a Political Market Square. Event Management, 7, 51-65.

Law, B.M., \& Shek, D.T. (2009). Beliefs about Volunteerism, Volunteering Intention, Volunteering Behavior, and Purpose in Life Among Chinese Adolescents in Hong Kong. The Scientific World Journal, 9, 855-865.

Lawler, E.J., \& Thye, S.R. (1999). Bringing Emotions into Social Exchange Theory. Annual Review of Sociology, 25, 217-244.

Lee, J., \& Guo, Y.Y. (2008). Materialism and the Relevant Studies. Advances in Psychological Science, 4, 20.

Leung, K. (1997). Negotiation and Reward Allocations across Cultures. In Earley, P.C. \& Erez, M. Eds. New Perspectives on International Industrial/Organizational Psychology. San Francisco, Jossey-Bass: 640-675.

Lew, A. A., \& Wong, A. (2004). Sojourners, guanxi and clan associations: social capital and overseas Chinese tourism to China. In T. Coles and D.J. Timothy (eds) Tourism, Diasporas, and Space, 202-214. London: Routledge.

Li, Y., Lai, K., \& Feng, X. (2007). The Problem of 'Guanxi' for Actualizing Community Tourism: A Case Study of Relationship Networking In China. Tourism Geographies: An International Journal of Tourism Space, Place and Environment, 9(2), 115-138.

Li, Y., \& Wood, E.H. (2016). Music Festival Motivation In China: Free the Mind. Leisure Studies, 35(3), 332-351.

Liao, H., Liu, D., \& Loi, R. (2010). Looking at Both Sides of the Social Exchange Coin: A Social Cognitive Perspective on the Joint Effects of Relationship Quality and Differentiation on Creativity. Academy of Management Journal, 53(5), 1090-1109.

Liden, R.C., Wayne, S.J., \& Sparrowe, R.T. (2000). An Examination of The Mediating Role of Psychological Empowerment on The Relationship Between Job, Interpersonal Relationships and Work Outcomes. Journal of Applied Psychology, 85, 407-416.

Love, M.S., \& Forret, M. (2008). Exchange Relationships at Work: An Examination of the Relationship between Team-Member Exchange and Supervisor Reports of Organizational Citizenship Behavior. Journal of Leadership \& Organizational Studies, 14(4), 342-352.

Martinaityte, I., \& Sacramento, C. A. (2013). When creativity enhances sales effectiveness: The moderating role of leader-member exchange. Journal of Organizational Behavior, 34(7), 974-994. Matta,V., Koonce, D., \& Jeyaraj, A. (2012). Initiation, Experimentation, Implementation of Innovations: The Case for Radio Frequency Identification Systems. International Journal of Information Management, 32, 164-174. 
McAdam, R. (2005). A multi-level theory of innovation implementation: Normative evaluation, legitimisation and conflict. European Journal of Innovation Management, 8(3), 373-388.

McAdam, R., Moffett, S., Hazlett, S.A., \& Shevlin, M. (2010) Developing a model of innovation implementation for UK SMEs: a path analysis and explanatory case analysis. International Small Business Journal, 28(3), 195-214.

Mead, M. (1937). Cooperation and Competition among Primitive Peoples. New York and London: Mcgraw-Hill.

Meeker, B.F. (1971). Decisions and Exchange. American Sociological Review, 36, 485-495.

Miles, M.B., \& Huberman, A.M. (1994). Qualitative Data Analysis: An Expanded Sourcebook. 2nd Ed. London: Sage.

Mohamed, M.Z. (1995). Innovation Implementations in Malaysian Firms: Process, Problems, Critical Success Factors and Working Climate. Technovation, 15(6), 375385.

Molm, L.D. (1994). Dependence and Risk: Transforming the Structure of Social Exchange. Social Psychology Quarterly, 57, 163-176.

Molm, L. D. (2000). Theories of Social Exchange and Exchange Networks. In: Ritzer, G. \& Smart, B. Eds. Handbook of Social Theory. Thousand Oaks, CA: Sage: 260272.

Molm, L.D. (2003). Theoretical Comparisons of Forms of Exchange. Sociological Theory, 21, 1-17.

Mortara, L., \& Minshall,T. (2011). How Do Large Multinational Companies Implement Open Innovation? Technovation, 31, 586-597.

Nieves, J., \& Segarra-Ciprés, M. (2015). Management Innovation in the Hotel Industry. Tourism Management, 46, 51-58.

Noordin, M. F., \& Karim, Z. A. (2015). Modeling the Relationship between Human Intelligence, Knowledge Management Practices, and Innovation Performance. Journal of Information \& Knowledge Management, 14(1), 155-212.

Osland, G. E. (1990). Doing Business in China: A Framework for Cross-Cultural Understanding. Marketing Intelligence and Planning, 8(4), 4-14.

Paleo, I.O., \& Wijnberg, N.M. (2008). Organizational Output Innovativeness: A Theoretical Exploration, Illustrated By a Case of a Popular Music Festival. Creativity and Innovation Management, 17(1), 3-13.

Paraskevaidis, P., \& Andriotis, K. (2017). Altruism in tourism: social exchange theory vs altruistic surplus phenomenon in host volunteering. Annals of Tourism Research, 62, 26-37. 
Park, S.H., \& Luo, Y. (2001). Guanxi and Organizational Dynamics: Organizational Networking in Chinese Firms. Strategic Management Journal, 22 (5), 455-477.

Parker, B. (1998). Globalization: Managing Across Boundaries. London: Sage.

Parsons, T. (1951). The Social System. Glencoe, Illinois: The Free Press.

Pennings, J.M., \& Harianto, F. (1992). Technological Networking and Innovation Implementation. Organization Science, 3(3), 356-382.

Pfeffer, J. (1994). Competitive Advantage through People. Boston: Harvard Business School Press.

Pye, L. (1982). Chinese Commercial Negotiating Style. Cambridge: Oelgeschlager, Gunnand Hain Inc.

Rapert, M. I., Velliquette, A., \& Garretson, J. A. (2002). The Strategic Implementation Process: Evoking Strategic Consensus through Communication. Journal of Business Research, 55, 301-310.

Repenning, N.P., \& Sterman, J.D. (2002). Capability Traps and Self-Confirming Attribution Errors in the Dynamics of Process Improvement. Administrative Science Quarterly, 47, 265-295.

Robinson, S. L., Kraatz, M. S., \& Rousseau, D. M. (1994). Changing Obligations and the Psychological Contract: A Longitudinal Study. Academy Of Management Journal, 37, 137-152.

Rodriguez, I., Williams, A.M., \& Hall, C.M. (2014). Tourism Innovation Policy: Implementation and Outcomes. Annals of Tourism Research, 49, 76-93.

Rousseau, D.M., \& Schalk, R. (2000). Psychological Contracts in Employment: Cross-National Perspectives. Thousand Oaks, CA: Sage.

Saunders, M., Lewis, P., \& Thornhill, A. (2007). Research Methods for Business Students. 4th Ed. Harlow: Pearson Education Limited.

Sawang, S., \& Unsworth, K.L. (2011). A Model of Organizational Innovation Implementation Effectiveness in Small to Medium Firms. International Journal of Innovation Management, 15(5), 989-1011.

Schilbach, T. (2010). Cultural policy in Shanghai: the politics of caution in the global city. Journal of Policy Research in Tourism, Leisure and Events, 2(3), 221-235.

Schumpeter, J.A. (2000). Capitalism, Socialism and Democracy. London: Routledge.

Seers, A., Petty, M. M., \& Cashman, J. F. (1995). Team-Member Exchange under Team and Traditional Management: A Naturally Occurring Quasi-Experiment. Group \& Organization Management, 20, 18-38.

Settoon, R. P., Bennett, N., \& Liden, R. C. (1996). Social Exchange in Organizations: Perceived Organizational Support, Leader-Member Exchange, and Employee Reciprocity. Journal of Applied Psychology, 81, 219-227. 
Shore, L. M., \& Coyle-Shapiro, J. A.-M. (2003). New Developments in the EmployeeOrganization Relationship. Journal of Organizational Behavior, 24, 443-450.

Shore, L. M., Tetrick, L. E., Lynch, P., \& Barksdale, K. (2001). Social and economic exchanges as mediators between commitment and performance. Journal of Applied Psychology.

Shalley, C. E., Zhou, J., \& Oldham, G. R. (2004). The Effects of Personal and Contextual Characteristics on Creativity: Where Should We Go From Here? Journal of Management, 30, 933-958.

Shaw, G. (2015). Tourism Networks, Knowledge Dynamics and Co-Creation. In Mcleod, M. And Vaughan, R. (Eds.), Knowledge Networks and Tourism, London: Routledge, 45-61.

Shaw, G., \& Williams, A.M. (2009). Knowledge Transfer and Management in Tourism Organisations: An Emerging Research Agenda. Tourism Management, 30(3), 325-335.

Simpson, D.D., \& Flynn, P.M. (2007) Moving innovations into treatment: a stagebased approach to program change. Journal of Substance Abuse Treatment, 33(2), 111-120.

Somech, A., \& Drach-Zahavy, A. (2013). Translating Team Creativity to Innovation Implementation the Role of Team Composition and Climate for Innovation. Journal of Management, 39(3), 684-708.

Sorensen, F. (2007). The Geographies of Social Networks and Innovation in Tourism. Tourism Geographies, 9(1), 22-48.

Starkweather, K.N. (2005). Innovation, TIDE Teachers, and the Global Economy. Technology Teacher, 65(2), 28-30.

Sung, S. Y., \& Choi, J. N. (2014). Do Organizations Spend Wisely On Employees? Effects of Training and Development Investments on Learning and Innovation in Organizations. Journal of Organizational Behavior, 35(3), 393-412.

Thomas, R. (2012). Business Elites, Universities and Knowledge Transfer in Tourism. Tourism Management, 33 (3), 553-561.

Thomas, R., \& Wood, E.H. (2014). Innovation in Tourism: Re-Conceptualising and Measuring the Absorptive Capacity of the Hotel Sector. Tourism Management, 45, 39-48.

Thomas, R., \& Wood, E.H. (2015). The Absorptive Capacity of Tourism Organisations. Annals of Tourism Research, 54, 84-99.

Tierney, P. (1992). The Contribution of Leadership, Supportive Environment, and Individual Attributes To Creative Performance: A Quantitative Field Study (Doctoral Dissertation, University of Cincinnati, 1992). Dissertation Abstracts International 54: 246. 
Tierney, P., \& Farmer, S. M. (2002). Creative Self-Efficacy: Its Potential Antecedents and Relationship to Creative Performance. Academy of Management Journal, 45, 1137-1148.

Tidd, J., \& Bessant, J. (2009). Managing Innovation: Integrating Technological, Market and Organizational Change. 4th Ed. Chichester: John Wiley \& Sons Ltd.

Triandis, H.C. (1990). Cross Cultural Studies of Individualism and Collectivism. In: Berman, J.J. Ed. Nebraska Symposium on Motivation 1989. Lincoln: University Of Nebraska Press, 41-133.

Triandis, H.C., Mccusker, C., \& Hui, C.H. (1990). Multimethod Probes of Individualism and Collectivism. Journal of Personality and Social Psychology, 59(5), 1006-1020.

Van De Ven, A. H., Angle, H. L., \& Poole, M. S. (1989). Research on the Management of Innovation: The Minnesota Studies. New York: Harper \& Row.

Van De Ven, A.H., Polley, D.E., Garud, R., \& Venkataraman, S. (2008). The Innovation Journey. Oxford: Oxford University Press.

Van De Vrande, V., De Jong, J. P. J., Vanhaverbeke, W., \& De Rochemont, M. (2009). Open Innovation In SMEs: Trends, Motives and Management Challenges. Technovation, 29, 423-437.

Van der Panne, G., Van der Beers, C., \& Kleinknecht, A. (2003). Success and failure of innovation: A literature review. International Journal of Innovation Management, 7(3), 309-338.

Van Limburg, B. (2008). Innovation in Pop Festivals by Cocreation. Event Management, 12, 105-117.

Venkatesh, V., Morris, M. G., Davis, G. B., \& Davis, F. D. (2003). User Acceptance of Information Technology: Toward A Unified View. MIS Quarterly, 27, 425-478.

Volmer, J., Spurk, D., \& Niessen, C. (2012). Leader-Member Exchange (LMX), Job Autonomy, and Creative Work Involvement. The Leadership Quarterly, 23, 456-465.

Walker, R. H., Craig-Lees, M., Hecker, R., \& Francis, H. (2002). Technology-Enabled Service Delivery: An Investigation of Reasons Affecting Customer Adoption and Rejection. International Journal of Service Industry Management, 13(1), 91-106.

Williams, A.M., \& Shaw, G. (2011). Internationalization and Innovation in Tourism. Annals of Tourism Research, 38(1), 27-51.

Wilson, K. S., Sin, H.-P., \& Conlon, D. E. (2010). What About The Leader In LeaderMember Exchange? The Impact of Resource Exchanges and Substitutability on the Leader. Academy of Management Review, 35, 358-372.

Weidenfeld, A. (2013). Tourism and Cross Border Regional Innovation Systems. Annals of Tourism Research, 42, $191-213$. 
Weidenfeld, A., Williams, A. M., \& Butler, R. W. (2010). Knowledge Transfer and Innovation among Attractions. Annals of Tourism Research, 37(3), 604 -626.

Yaghmour, S., \& Scott, N. (2009). Inter-Organizational Collaboration Characteristics and Outcomes: A Case Study of the Jeddah Festival. Journal of Policy Research in Tourism, Leisure and Events, 1, 115-130.

Yu, C., Holroyd, E., Cheng, Y., \& Lau, J. T. F. (2013). Institutional Incentives for Altruism: Gifting Blood In China. BMC Public Health, 13(1), 524.

Yuan, Y., \& Tan, J. (2011). Zhongguo Zhiyuan Fuwu: Cong Shequ Dao Shehui [Volunteerism in China: From Community to Society]. Beijing: Renmin Chubanshe.

Zhang, Y., \& Lin, J. (2008). Volunteerism in China II: Implementation, Issues, and Challenges: Guest Editors' Introduction to Part II. Chinese Education \& Society, 41(4), 3-12.

Zhang, Y., \& Zhang, Z. (2006). Guanxi and Organizational Dynamics in China: A Link between Individual and Organizational Levels. Journal of Business Ethics, 67, 375-392.

Zhao, S. N., \& Timothy, D. J. (2015). Governance of red tourism in China: Perspectives on power and guanxi. Tourism Management, 46, 489-500.

Zhuang, J. (2010). Beijing 2008: Volunteerism in Chinese Culture and Its Olympic Interpretation and Influence. The International Journal of the History of Sport, 27(1618), 2842-2862.

Ziakas, V., \& Costa, C.A. (2010). Explicating Inter-Organizational Linkages of a Host Community's Events Network. International Journal of Event and Festival Management, 1(2), 132-147. 
Figure 1 Factors considered relevant to the successful implementation of innovation

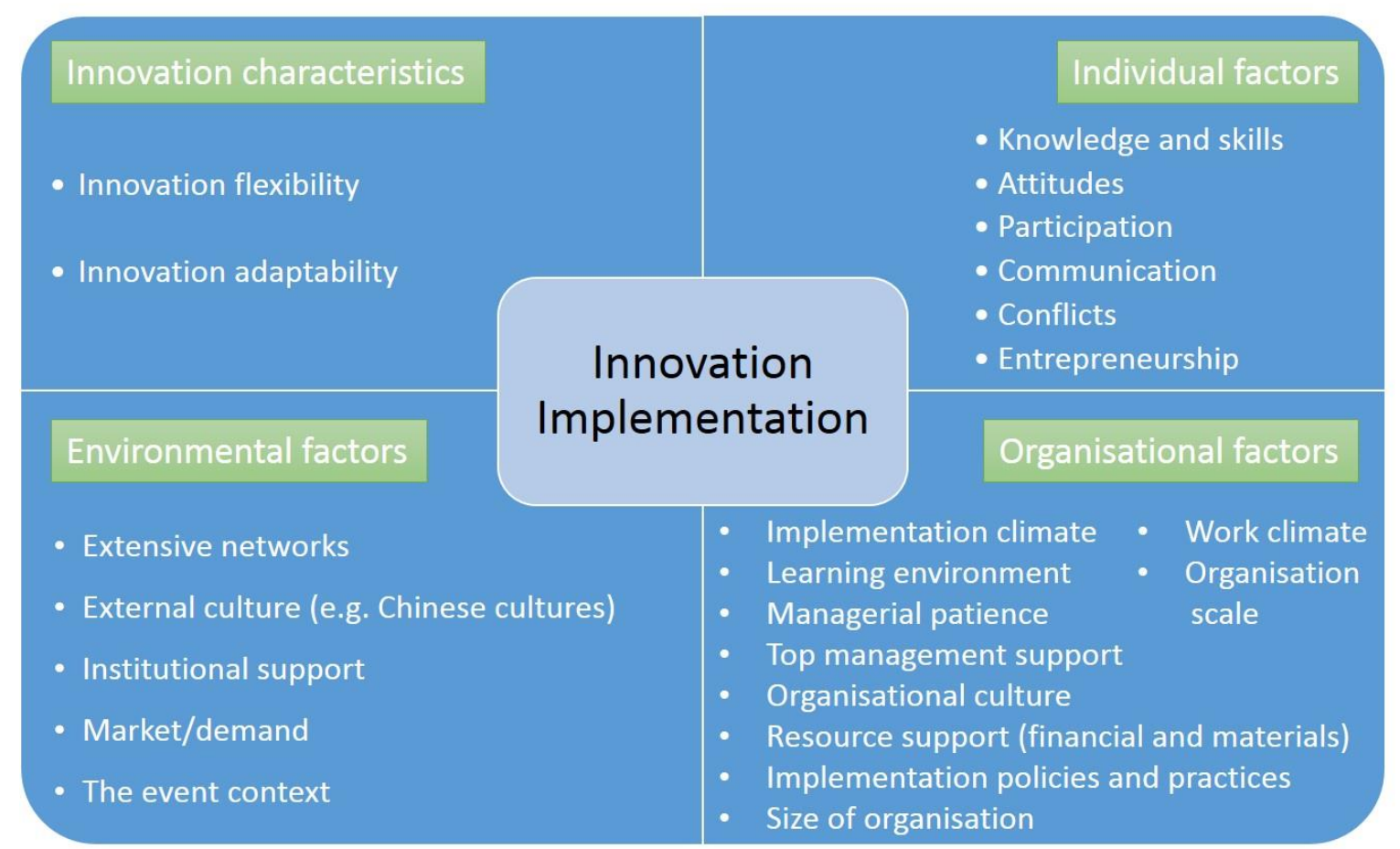

Sources : Axtell et al. (2000), Cadwallader et al. (2010), Choi \& Moon (2014), Hausman \& Stock (2003), Hamdani \& Wirawan (2012), Hjalager (2010), Klein \& Knight (2005), Klein \& Sorra (1996), Klein et al. (2001), Matta et al. (2012), McAdam (2005), McAdam et al. (2010), Mohamed (1995), Mortara \& Minshall (2011), Pennings \& Harianto (1992), Rapert et al. (2002), Repenning \& Sterman (2002), Sawang \& Unsworth (2011), Simpson \& Flynn (2007), Sung \& Choi (2014), Tidd \& Bessant (2009), Van de Ven et al. (1989), Van de Vrande et al. (2009), Van der Panne et al. (2003). 
Figure 2 Illustration of how different rules and norms of social exchange affect exchange relationships

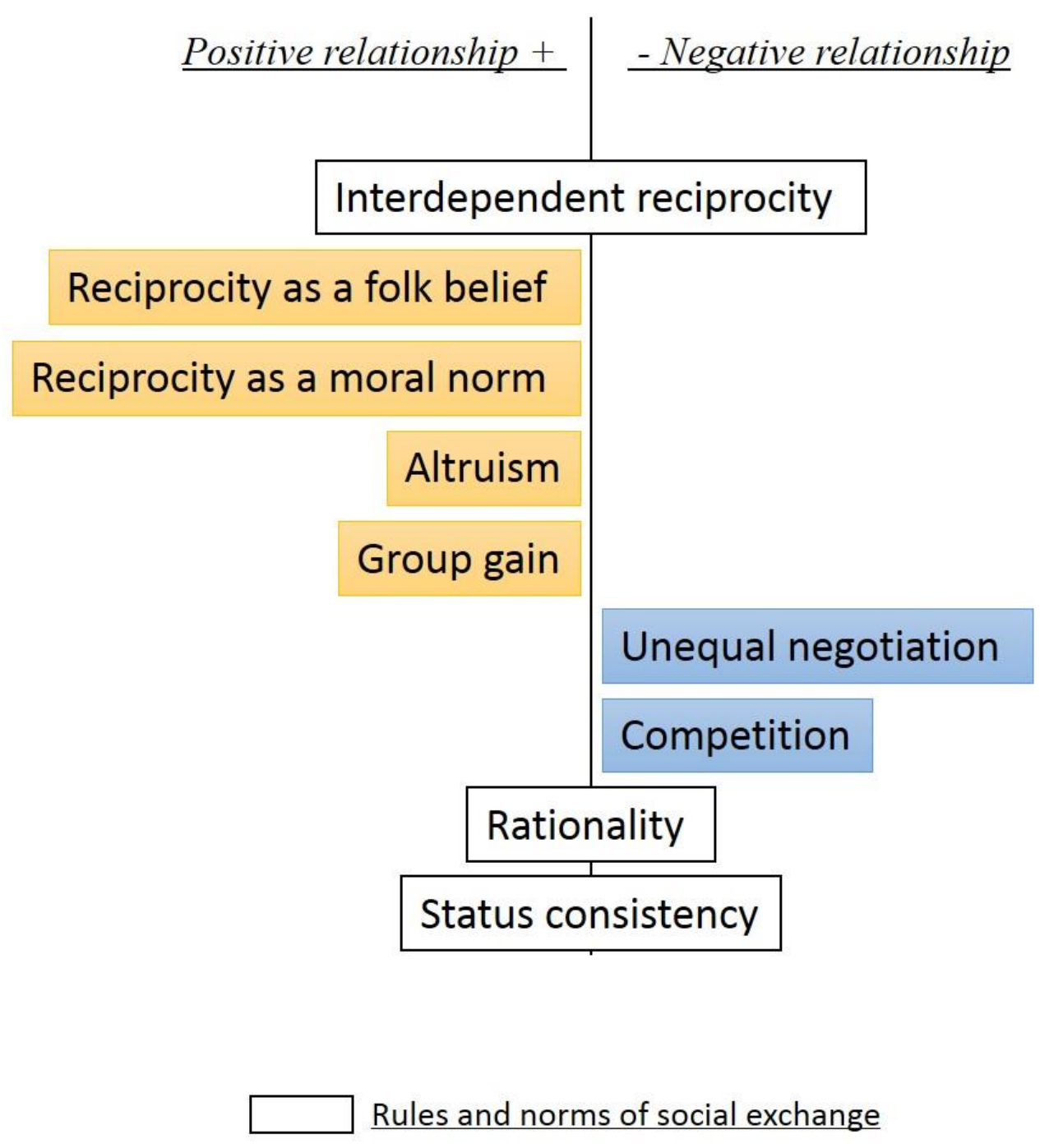


Adopted from: Chan (1963), Cropanzano \& Mitchell (2005), Hui et al. (2008), Meeker (1971),

Molm (2000, 2003)

Table 1 Overview of the six music festivals

\begin{tabular}{|c|c|c|c|}
\hline & Level & Location & Organisational structure \\
\hline Festival 1 & Regional & Small county & $\begin{array}{l}\text { Local government (host, operation) } \\
\text { Outsourced one professional team or } \\
\text { company (operation, not local) }\end{array}$ \\
\hline Festival 2 & Regional & $\begin{array}{l}\text { Capital city of } \\
\text { province }\end{array}$ & $\begin{array}{l}\text { Private company (host, in charge, not local) } \\
\text { Local government controlled company } \\
\text { (partnership, local) } \\
\text { Outsourced multiple professional teams or } \\
\text { companies (operation, some local) }\end{array}$ \\
\hline Festival 3 & Regional & $\begin{array}{l}\text { Capital city of } \\
\text { province }\end{array}$ & $\begin{array}{l}\text { Private company A (main body, local) } \\
\text { Private company B (partnership, local) } \\
\text { Private company C (partnership, local) } \\
\text { Outsourced multiple professional teams or } \\
\text { companies (operation, some local) }\end{array}$ \\
\hline Festival 4 & Regional & $\begin{array}{l}\text { Capital city of } \\
\text { province }\end{array}$ & $\begin{array}{l}\text { City-level government owned company A } \\
\text { (operation, local) } \\
\text { Province-level government owned company } \\
\text { B (operation, local) }\end{array}$ \\
\hline Festival 5 & National & $\begin{array}{l}\text { Mega modern } \\
\text { city }\end{array}$ & $\begin{array}{l}\text { Private company (not local) } \\
\text { Outsourced professional team (operation, } \\
\text { local) }\end{array}$ \\
\hline Festival 6 & National & $\begin{array}{l}\text { Mega modern } \\
\text { city }\end{array}$ & Private company (local) \\
\hline
\end{tabular}


Table 2 Summary of main methods used in the six case studies

\begin{tabular}{|c|c|c|c|c|c|}
\hline Main methods & $\begin{array}{l}\text { Number } \\
\text { of } \\
\text { Interviews }\end{array}$ & $\begin{array}{l}\text { Direct } \\
\text { observation }\end{array}$ & $\begin{array}{l}\text { Participant } \\
\text { observation }\end{array}$ & $\begin{array}{l}\text { Online group } \\
\text { discussion } \\
\text { observation }\end{array}$ & $\begin{array}{l}\text { Weibo } \\
\text { observation }\end{array}$ \\
\hline Festival 1 & 22 & 9 days & 9 days & None & $\begin{array}{l}8 \\
\text { participants }\end{array}$ \\
\hline Festival 2 & 33 & 7 days & 7 days & None & $\begin{array}{l}6 \\
\text { participants }\end{array}$ \\
\hline Festival 3 & 16 & 3 days & 3 days & None & None \\
\hline Festival 4 & 13 & 3 days & 3 days & 5 months & $\begin{array}{l}8 \\
\text { participants }\end{array}$ \\
\hline Festival 5 & 22 & 3 days & 3 days & None & None \\
\hline Festival 6 & 22 & 3 days & 3 days & 1 month & None \\
\hline
\end{tabular}


Table 3 Profile of interviewees

\begin{tabular}{l|l|l|l|l|l}
\hline Music festival & $\begin{array}{l}\text { Number of } \\
\text { interviews }\end{array}$ & $\begin{array}{l}\text { Org staff } \\
\text { (High-medium } \\
\text { level) }\end{array}$ & $\begin{array}{l}\text { Org staff } \\
\text { (Low } \\
\text { level) }\end{array}$ & $\begin{array}{l}\text { Partners/ } \\
\text { Suppliers }\end{array}$ & Volunteers \\
\hline $\mathbf{1}$ & 22 & 7 & 8 & 3 & 4 \\
\hline $\mathbf{2}$ & $\mathbf{3 3}$ & 4 & 14 & 0 & 15 \\
\hline $\mathbf{3}$ & $\mathbf{1 6}$ & 1 & 3 & 1 & 11 \\
\hline $\mathbf{4}$ & $\mathbf{1 3}$ & 0 & 1 & 0 & 12 \\
\hline $\mathbf{5}$ & $\mathbf{2 2}$ & 2 & 0 & 2 & 18 \\
\hline $\mathbf{6}$ & $\mathbf{2 2}$ & 6 & 2 & 1 & 13 \\
\hline Total & $\mathbf{1 2 8}$ & 20 & 28 & 7 & 73 \\
\hline
\end{tabular}


Table 4 Overview of the 11 innovations identified 


\begin{tabular}{|c|c|c|c|c|}
\hline $\begin{array}{l}\text { Music } \\
\text { festival }\end{array}$ & Innovation & Category & Actors involved & Key features \\
\hline 1 & $\begin{array}{l}\text { I-mart } \\
\text { A market } \\
\text { designed for } \\
\text { traders to sell } \\
\text { handmade or } \\
\text { original } \\
\text { products }\end{array}$ & Product & $\begin{array}{ll}\text { - } & \text { Government } \\
\text { - } & \text { Festival director } \\
\text { - } & \text { Logistic staff } \\
\text { - } & \text { I-mart manager } \\
\text { - } & \text { I-mart manager assistant } \\
\text { - } & \text { I-mart junior staff } \\
\text { - } & \text { I-mart volunteers } \\
\text { - } & \text { I-mart traders } \\
\text { - } & \text { Unauthorised traders }\end{array}$ & $\begin{array}{ll}\text { - } & \text { Institutional support } \\
\text { - } & \text { Government support } \\
\text { - } & \text { Knowledge intensive } \\
\text { - } & \text { Volunteer } \\
& \text { management } \\
\text { - } & \text { Multiple party } \\
& \text { cooperation }\end{array}$ \\
\hline & $\begin{array}{l}\text { Campsite } \\
\text { Unusual in } \\
\text { Chinese } \\
\text { festivals }\end{array}$ & Product & $\begin{array}{ll}\text { - } & \text { Campsite director } \\
\text { - } & \text { Campsite supervisor } \\
\text { - } & \text { Campsite staff } \\
\text { - } & \text { Campsite security } \\
\text { - } & \text { Campsite volunteers } \\
\text { - } & \text { Campsite volunteer } \\
& \text { supervisor }\end{array}$ & $\begin{array}{ll}\text { - } & \text { Institutional support } \\
\text { - } & \text { Knowledge intensive } \\
\text { - } & \text { Staff management }\end{array}$ \\
\hline 2 & $\begin{array}{l}\text { Festival } \\
\text { representatives } \\
\text { Similar to } \\
\text { holiday camp } \\
\text { representatives } \\
\text { and new in } \\
\text { China }\end{array}$ & Process & $\begin{array}{ll} & \text { Director } \\
\text { - } & \text { Managers } \\
\text { - } & \text { Supervisor } \\
\text { - } & \text { Festival 'angels' }\end{array}$ & $\begin{array}{ll} & \text { Volunteer } \\
& \text { management }\end{array}$ \\
\hline \multirow[t]{2}{*}{3} & $\begin{array}{l}\text { Secondary } \\
\text { stage } \\
\text { New to the } \\
\text { festival }\end{array}$ & Product & 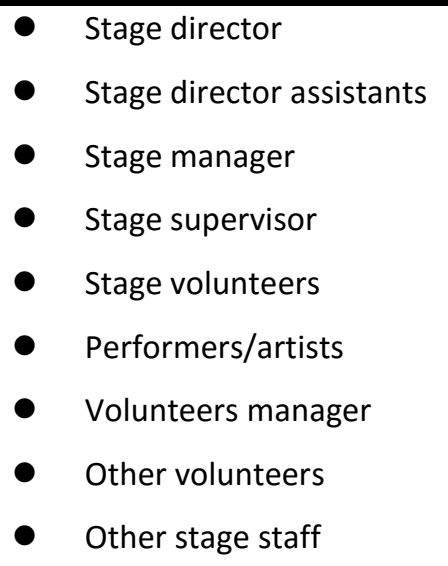 & $\begin{array}{ll}\text { - } & \text { Multiple party } \\
\text { cooperation } \\
\text { - } \\
\text { insources } \\
\text { insufficient } \\
\text { Volunteer } \\
\text { management }\end{array}$ \\
\hline & $\begin{array}{l}\text { Artists signing } \\
\text { autographs and } \\
\text { album selling } \\
\text { New to the } \\
\text { festival }\end{array}$ & Product & $\begin{array}{ll}\text { - } & \text { Sector volunteers } \\
\text { - } & \text { Other volunteers } \\
\text { - } & \text { Stage staff }\end{array}$ & $\begin{array}{ll} & \text { Resources } \\
& \text { insufficient } \\
\text { - } & \text { Volunteer } \\
& \text { management } \\
\text { - } & \text { Communication }\end{array}$ \\
\hline
\end{tabular}




\begin{tabular}{|c|c|c|c|c|c|c|}
\hline & $\begin{array}{l}\text { Photography } \\
\text { team to record } \\
\text { live scenes the } \\
\text { festival } \\
\text { New to the } \\
\text { festival }\end{array}$ & Process & - & $\begin{array}{l}\text { Photography team } \\
\text { manager } \\
\text { Photography team } \\
\text { volunteers } \\
\text { Other volunteers } \\
\text { Stage staff } \\
\text { Festival-goers } \\
\text { Volunteers manager }\end{array}$ & $\bullet$ & $\begin{array}{l}\text { Resources } \\
\text { insufficient } \\
\text { Communication }\end{array}$ \\
\hline \multirow[t]{2}{*}{4} & $\begin{array}{l}\text { Recycling and } \\
\text { green } \\
\text { messenger } \\
\text { team } \\
\text { To promote the } \\
\text { idea of } \\
\text { environment } \\
\text { protection and } \\
\text { ensure the } \\
\text { cleanness of } \\
\text { the festival site }\end{array}$ & Process & $\bullet$ & $\begin{array}{l}\text { Volunteers manager } \\
\text { (Organisation A) } \\
\text { Recycling and green } \\
\text { messenger volunteers } \\
\text { (Organisation A) } \\
\text { Other volunteers } \\
\text { (Organisation A) } \\
\text { Organisation B staff } \\
\text { Volunteers (Organisation } \\
\text { B) }\end{array}$ & $\bullet$ & $\begin{array}{l}\text { Multiple parties } \\
\text { cooperation } \\
\text { Resources } \\
\text { insufficient } \\
\text { Communication }\end{array}$ \\
\hline & $\begin{array}{l}\text { Photography } \\
\text { team } \\
\text { To record the } \\
\text { live scene of } \\
\text { the festival } \\
\text { New to the } \\
\text { festival }\end{array}$ & Process & $\bullet$ & $\begin{array}{l}\text { Volunteers manager } \\
\text { (Organisation A) } \\
\text { Photography team } \\
\text { volunteers (Organisation } \\
\text { A) } \\
\text { Other volunteers } \\
\text { (Organisation A) } \\
\text { Organisation B staff } \\
\text { Volunteers (Organisation } \\
\text { B) }\end{array}$ & $\bullet$ & Communication \\
\hline \multirow[t]{2}{*}{5} & $\begin{array}{l}\text { Complaint } \\
\text { center } \\
\text { New to the } \\
\text { festival }\end{array}$ & Process & $\bullet$ & $\begin{array}{l}\text { Centre managers } \\
\text { Centre volunteers } \\
\text { Other festival } \\
\text { organisation staff } \\
\text { Venue staff }\end{array}$ & $\bullet$ & $\begin{array}{l}\text { Multiple parties } \\
\text { cooperation } \\
\text { Resources } \\
\text { insufficient }\end{array}$ \\
\hline & $\begin{array}{l}\text { Volunteer } \\
\text { management }\end{array}$ & Managerial/ & $\bullet$ & $\begin{array}{l}\text { Volunteer managers } \\
\text { (Volunteer management }\end{array}$ & $\bullet$ & $\begin{array}{l}\text { Multiple parties } \\
\text { cooperation }\end{array}$ \\
\hline
\end{tabular}




\begin{tabular}{|c|c|c|c|c|}
\hline & $\begin{array}{l}\text { First time of } \\
\text { outsourcing } \\
\text { volunteer } \\
\text { management to } \\
\text { an external } \\
\text { organisation }\end{array}$ & organisational & $\begin{array}{ll}\text { - } & \text { organisation) } \\
\text { (Volunteer team leaders } \\
\text { (Volunteer management } \\
\text { organisation) } \\
\text { - } & \text { Volunteers } \\
\text { - } & \text { Music festival } \\
\text { - } & \text { Musganisation festival } \\
\text { organisation's own } \\
\text { volunteers }\end{array}$ & - Knowledge intensive \\
\hline 6 & $\begin{array}{l}\text { Campsite } \\
\text { Unusual in } \\
\text { Chinese } \\
\text { festivals }\end{array}$ & Product & $\begin{array}{ll}\text { - } & \text { Campsite director } \\
\text { - } & \text { Campsite staff } \\
\text { - } & \text { Campsite volunteers } \\
\text { - } & \text { Festival organisation } \\
& \text { staff } \\
\text { - } & \text { Government }\end{array}$ & $\begin{array}{ll}\text { - } & \text { Institutional support } \\
\text { - } & \text { Knowledge intensive } \\
\text { - } & \text { Volunteer } \\
& \text { management }\end{array}$ \\
\hline
\end{tabular}


Table 5 Summary of the implementation outcomes

\begin{tabular}{|c|c|c|}
\hline $\begin{array}{l}\text { Innovation implementation } \\
\text { outcome }\end{array}$ & Innovation (music festival case number) & Relationships* \\
\hline $\begin{array}{l}\text { Satisfied stakeholder and } \\
\text { efficient process }\end{array}$ & Complaint center (case five) & $\mathrm{HF}$ \\
\hline $\begin{array}{l}\text { Satisfied stakeholder and } \\
\text { inefficient process }\end{array}$ & Photography team (case four) & $\mathrm{HF}, \mathrm{CD}$ \\
\hline \multirow{6}{*}{$\begin{array}{l}\text { Dissatisfied stakeholder and } \\
\text { minor consequence }\end{array}$} & Festival representatives (case two) & $\mathrm{HF}, \mathrm{CD}$ \\
\hline & Secondary stage (case three) & $\mathrm{HF}, \mathrm{HD}, \mathrm{CD}$ \\
\hline & $\begin{array}{l}\text { Artists signing autographs and album selling } \\
\text { (case three) }\end{array}$ & $\mathrm{HF}, \mathrm{CD}$ \\
\hline & Photography team (case three) & $\mathrm{HF}, \mathrm{HD}$ \\
\hline & $\begin{array}{l}\text { Recycling and green messenger team (case } \\
\text { four) }\end{array}$ & $\mathrm{HF}, \mathrm{CD}$ \\
\hline & Volunteer management (case five) & $\mathrm{HF}, \mathrm{HD}, \mathrm{CD}$ \\
\hline \multirow{3}{*}{ Dissati } & I-mart (case one) & $\mathrm{HF}, \mathrm{HD}, \mathrm{CD}, \mathrm{CF}$ \\
\hline & Campsite (case two) & $\mathrm{HF}, \mathrm{CD}$ \\
\hline & Campsite (case six) & $\mathrm{HF}, \mathrm{HD}$ \\
\hline
\end{tabular}

${ }^{*}$ Relationships: $\mathrm{HF}=$ harmonious-functional, $\mathrm{HD}=$ harmonious-dysfunctional, $\mathrm{CD}=$ conflictingdysfunctional, $\mathrm{CF}=$ conflicting-functional. These are discussed later in the paper. 
Figure 3 The role and influence of relationships on the implementation of innovation within the context of modern Chinese music festivals

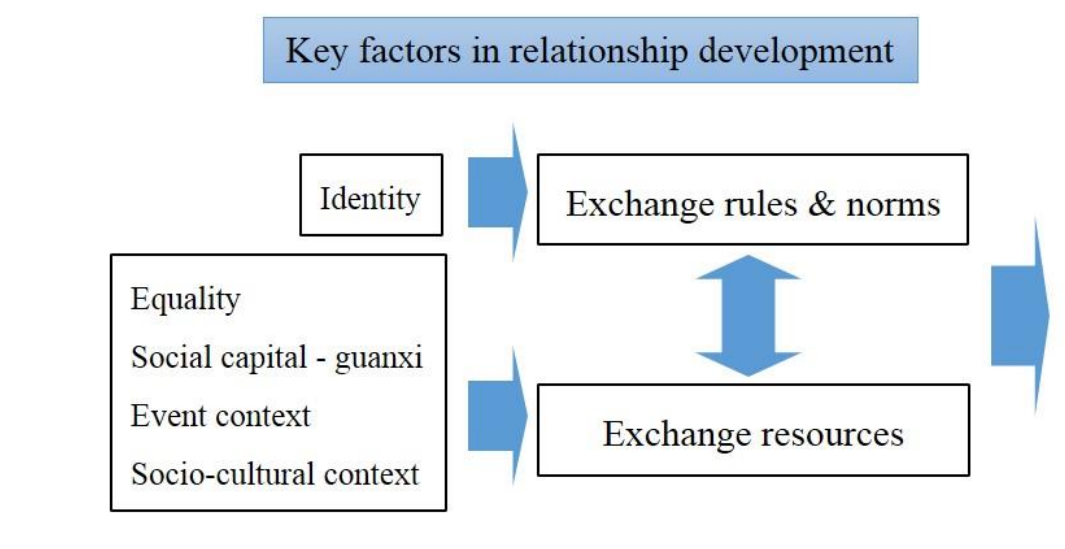

Types of relationship

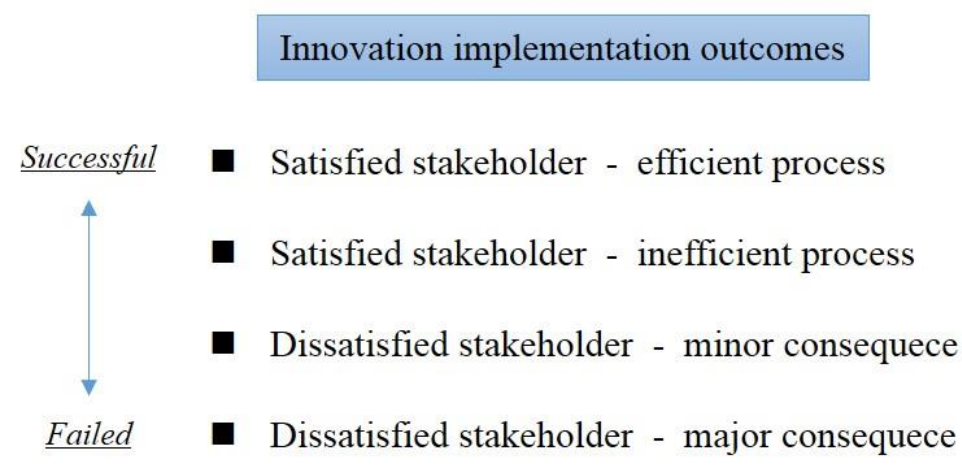
A. Harmonious-Functional
B. Harmonious-Dysfunctional
C. Conflicting-Dysfunctional
D. Conflicting-Functional
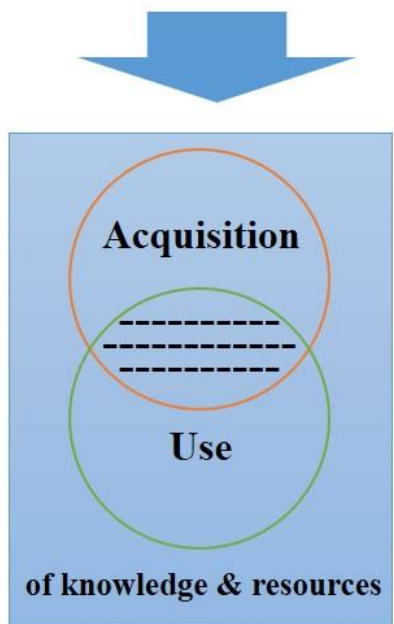

Influence

Source: authors 